УДК 378.046:37:004]

Лещенко Марія Петрівна, доктор педагогічних наук, професор, провідний науковий співробітник інформаційно-аналітичного відділу педагогічних інновацій Інституту інформаційних технологій i засобів навчання НАПН України, м. Київ, darlyngpetra@gmail.com.

Капустян Інга Іванівна, старший викладач кафедри англійської та німецької філології Полтавського національного педагогічного університету імені В. Г. Короленка, м. Полтава

\title{
КОЛАБОРАТИВНИЙ ПІДХД ДО РОЗВИТКУ ІКТ КОМПЕТЕНТНОСТЕЙ УЧИТЕЛІВ І УЧНІВ ЗАГАЛЬНООСВІТНІХ НАВЧАЛЬНИХ ЗАКЛАДІВ ШВЕЦЇ̈
}

\section{Анотація \\ У статті характеризується шведський досвід колаборативного підходу до} післядипломного навчання педагогів на базі загальноосвітніх навчальних закладів, що полягає у створенні партнерських умов взаємодії учителів 3 учнями в ході колективної проектної діяльності. 3'ясовано, що основними складовими ІКТ компетентності шведського вчителя $є$ мотиваційна, технологічна, рефлексивнопедагогічна. Показано, що зусилля шведських освітніх менеджерів спрямовані на практичне оволодіння учителями й учнями IKT компетентностями в реаліях природного навчального процесу, який носить, водночас, дослідницький та прагматично-орієнтований характер.

Ключові слова: шведський досвід, ІКТ в освіті, колаборативний підхід, мотиваційна, технологічна, рефлексивно-педагогічна компетентність.

Актуальність дослідження. Інформатизація суспільства, що покликана розв'язати значну кількість важливих завдань сучасної освіти як на світовому рівні, так і на рівні окремо взятих країн і регіонів, актуалізувала проблему підготовки вчителя до застосування ІКТ й ефективної педагогічної діяльності у навчальному комп'ютерно орієнтованому середовищі. Для українського освітнього простору в реаліях інформаційного суспільства набули особливої значущості й гостроти питання забезпечення високого рівня інформатизації освіти, що передбачає оволодіння 
педагогами вміннями впроваджувати в навчально-виховні практики електронні навчальні ресурси, спілкуватися в Інтернеті й керувати проектною діяльністю учнів із застосуванням IКТ й інтегрувати IКТ з предметними освітніми галузями.

Виклад основного матеріалу. Визначення сучасних методологічних орієнтирів творення і розвитку навчального комп'ютерно орієнтованого середовища потребує широкого розгортання порівняльно педагогічних досліджень. У цьому контексті значний інтерес становить досвід Швеції. За даними світового економічного форуму про розвиток інформаційних технологій у різних країнах Швеція очолює рейтинг за індексом мережної готовності (Global Information Technological Report 2012, Networked Readinnes Index, NRI). Цю лідерську позицію у застосуванні IKT технологій у різних сферах соціуму Швеція утримує упродовж п’яти років (20082012pp.) [9].

Управління системою освіти у Швеції покладено на Міністерство освіти i створювані ним комісії, що розробляють окремі освітні програми й готують реформи окремих ступенів освіти. Освіта на всіх ступенях - від середньої до вищої школи безкоштовна. Основною характеристикою шведської системи освіти є їі масовість та демократичність. Державне планування передбачає стовідсоткове охоплення молоді середньою освітою та прагне звести до мінімуму обмеження щодо прийому у вищі навчальні заклади (обмеження офіційно визначаються тільки термінами подання заяв і термінами реєстрації). Середня освіта у Швеції починається у віці 7 років (мережа дошкільних закладів охоплює усіх дітей з 3 до 7 років). Загальна середня шкільна освіта триває 9 років на трьох вікових етапах - молодшому, середньому та старшому. Після завершення загальної середньої освіти надається можливість продовжити їі в інтегрованій школі (High School), або ж почати трудову діяльність та подальшу освіту поєднувати 3 роботою. Інтегрована середня школа передбачає близько 26 варіантів вибору програми у трьох основних напрямах: за однорічними професійно орієнтованими програмами, дворічні технічні програми i трирічні академічні програми. Усі типи програм пов'язані 3 між собою, й учні мають практично необмежені можливості переходів з одних програм на інші. Попри це, як середня, так і вища освіта може бути отримана в різних навчальних закладах для дорослих (відкритих університетах). 
Інтенсивну інформатизацію загальноосвітніх навчальних закладів Міністерство освіти Швеції розпочало у 1998 році шляхом реалізації плану дій «ІКТ в системі освіти» (1998-2003 рр.), стратегічними напрямами якого було визначено:

- забезпечення всіх шкіл якісними засобами комунікації;

- створення локальної шкільної мережі інтранет;

- розвиток підходів до впровадження ІКТ у загальноосвітні навчальні заклади Швеції;

- підготовка вчителів до використання ІКТ у педагогічній діяльності;

- проведення різних курсів і занять з оволодіння цифровою компетентністю;

- надання після закінчення навчання відповідного сертифікованого документа;

- адаптування навчальних курсів відповідно до розвитку ІКТ у навчальному середовищі освітнього закладу;

- сприяння розробці мережних (on-line) курсів для реалізації концепції навчання протягом життя;

- покращення координації між науково-дослідними інституціями у сфері застосування IКТ [5, 23].

Розглядаючи проблему інтеграції IКT у неперервному педагогічному освітньому процесі Швеції, слід зазначити, що на сучасному етапі уряд країни визначив національну стратегію застосування ІКТ у змісті шкільної освіти, яка базуються на системному комплексному підході та спрямована на загальношкільне впровадження ІКТ у навчально-виховний процес. Швеція не стоїть осторонь від загальноєвропейського процесу модернізації освіти, від рефлективних процесів та викликів суспільства, щодо інформатизації освіти в цілому. Значна увага приділяється матеріально-технічному, програмному, методичному забезпеченню щодо використання ІКТ у навчально-виховному процесі загальноосвітньої школи. Стратегія викладання предметів циклу суспільствознавчих дисциплін з використанням IКТ, які $\epsilon$ предметами базового навчального плану, а саме: історія, географія, громадянська освіта, релігійне виховання, побудована на загальних принципах використання IКТ у змісті освіти і враховує специфіку кожного предмета.

На сьогоднішній день у загальноосвітніх закладах Швеції розроблені певні стандарти, що визначають роль і місце ІКТ для професійного розвитку і планування 
змісту, форм i методів навчання предметам суспільствознавчого циклу 3 використанням IКТ з 1-го по 12-ий клас загальноосвітньої школи. Основні знання, уміння, навички і стратегії, якими має володіти учень, що формуються засобами IКТ, включають дослідницькі, інформаційні та технологічні навички, які окреслені певними групами стандартів, а саме: місцезнаходження інформації; дослідження інформації, організація інформації у зручній формі, структурування у придатному для використання вигляді, використання комп'ютерно орієнтованих та медійних технологій [5].

У даний час набувала поширення концепція компетентнісного підходу в середній освіті Швеції, що є основою змістових змін із забезпечення відповідності освіти запитам і можливостям суспільства періоду інформатизації і глобальної масової комунікації. Значну роль у створенні умов для розвитку ІК-компетентності вчителів у сучасній системі неперервної освіти Швеції відіграє ефективно спланований двовекторний механізм, що реалізується у таких формах навчальної діяльності як: навчання на виробництві (in-service training) та професійна підготовка на базі університетів (pre-service training). Завдання освітньої системи післядипломного навчання на базі загальноосвітніх навчальних закладів полягало у створенні партнерських умов взаємодії учителів з учнями під час застосовування ІКТ у викладанні предметів шкільної програми.

У вітчизняній науковій літературі поняття ІКТ-компетентності має різноманітне трактування. Попередніми дослідженнями встановлено, що інформаційно-комунікаційна компетентність це підтверджена здатність особистості на практиці використовувати інформаційно-комунікаційні технології для задоволення власних індивідуальних потребі розв’язання суспільно значущих, зокрема професійних задач у певній предметній галузі. Українськими вченими також було розкрито зміст ключових компетентностей під час застосування інформаційних i комунікаційних технологій (В. Ю. Биков, М. І. Жалдак, Н. В. Морзе, О. В. Овчарук та ін.) $[1,2]$. Вони передбачають здатність орієнтуватися в інформаційному просторі, отримувати інформацію й оперувати нею відповідно до власних потреб і вимог сучасного високотехнологічного інформаційного суспільства.

Найближче за змістом до шведського трактування IКТ компетентностей вчителя є означення О. В. Овчарук, яка стверджує, що інформаційно-комунікаційна 
компетентність як ключова категорія розглядається як комплексне поняття, а саме сукупність знань і розуміння, умінь і навичок, а також особистісних ставлень i ціннісних орієнтацій людини у галузі ІКТ та здатність автономно й відповідально демонструвати їх для практичної, професійної діяльності та навчання впродовж життя [2].

3’ясовано, що основними складовими ІКТ-компетентності шведського вчителя $\epsilon$ мотиваційна, технологічна, рефлексивно-педагогічна. Мотиваційна складова вказує на наявність мотиву досягнення мети, готовність й інтерес до роботи, постановку й усвідомлення цілей діяльності. Вона включає здатність до подолання психологічного бар'єру під час освоєння ІКТ, потреби, прагнення до ІКТ-знань, ідентифікації власної особистості як «Я - комунікат»; технологічна складова розкривається як наявність знань, умінь і здатність застосовувати їх у професійній діяльності; уміння аналізувати, класифікувати і систематизувати програмні засоби. Вона демонструє ефективність і продуктивність діяльності, застосування на практиці набутих знань $\mathrm{i}$ вмінь.

Наявність технологічної або цифрової (від англ. сл. digital) компетентності означає, що учитель уміє користуватися програмами: текстові процесори (word processors), дизайн презентацій (presentation designer), табличні процесори (spreadsheets), бази даних (databases), навчальне програмне забезпечення (computer aided instruction software), засоби розробки сайтів (web page development tools), пошукові системи (search engines), електронний поштовий клієнт (e-mail), списки обговорення і групи новин (discussion lists and newsgroups), чати і форуми (chat and forum), електронні енциклопедіï, атласи (electronic encyclopedia or atlas), браузери (browsers), мультимедійні засоби (instructional films); рефлексивно-педагогічна складова забезпечує готовність до пошуку розв'язання навчальних проблем, до їх творчого перетворення на основі аналізу своєї діяльності, у зв'язку з тим, що обсяг знань й умінь не забезпечують необхідний розвиток потенціалу особи. Рефлексивнопедагогічна компетентність виявляється у здатності здійснювати мережну (міжособистісну, особистісно-технологічну, особистісно-інформаційну) педагогічну взаємодію.

На особливу увагу заслуговує шведський досвід колаборативного підходу до розвитку ІКТ компетентностей учителів і учнів загальноосвітніх навчальних закладів 
Швеції $[6,8]$. Важливою характеристикою високо компетентного вчителя є здатність до колаборативного навчання. Згідно із семантичним значенням слова у перекладі 3 англійської колаборація «collaboration» означає працювати разом задля досягнення спільної мети. Це рекурсивний процес, коли суб'єкти діяльності з бажанням i прагненням налаштовані на співпрацю, вибудову консенсусу в досягненні результативності поставленого завдання. Учасники мають характеризуватися достатньою комунікативністю й ініціативністю. Взаємини між учасниками колаборотивної групи детермінуються такими характеристиками, як: демократичність, рівноправність, автономність. Колаборативне навчання, як форма взаємодії під час навчально-виховного процесу потребує від вчителів роботи в команді з колегами й учнями, а також обговорення планів і результатів з учителемінструктором.

Під час колаборативного навчання спостерігається акцентуалізація не на індивідуальному завершенні завдання як під час кооперативної взаємодії, а на динаміці розвитку співпраці у рамках колаборативної групи. Шведські педагоги відзначають, що певною мірою кооперативне і колаборативне навчання мають схожі та диференційовані риси. Як подібні явища, вони характеризуються спільним виконанням поставленої мети, але різняться за природою інтерактивних процесів під час виконання завдань у межах групи.

Кооперативна співпраця вимагає розподілу завдань між учасниками робочої групи, де кожен відповідає за окрему частину висвітлення проблеми за подальшого їх результативного поєднання для досягнення поставленої мети. Колаборативна співпраця включає взаємне залучення учасників до взаємодії за допомогою координованих зусиль для розв’язання проблемних ситуацій. Такий підхід не применшує відповідальності учасника колаборативної групи за виконане завдання.

Водночас варто зазначити, що під час колаборативного навчання ролі учителя й учнів змінюються у часовому просторі співпраці залежно від суті, природи самого проблемного завдання. Розподіл завдань під час роботи у групі присутній за кооперативного та колаборотивного навчань. Важливим $є$ не сам розподіл завдань, а спосіб, яким результативно розв'язується поставлене завдання. Під час колаборативного навчання реалізується інтегрований та координований підхід. 
Розглянемо приклад колаборативного навчання під час викладання предметів суспільствознавчого циклу, а саме історії Європи. Учитель розподіляє клас на групи 3 5 чоловік. Кожна група отримує частину загальної програмної теми, наприклад, «Розвиток Німеччини II Рейху». Ця тема розподіляється на кілька підтем і кожна група отримує своє завдання. На виконання поставленого завдання учням надається три тижні часу. Під час виконання проектного завдання учні використовують як мережне спілкування, так і особистісне, що дозволяє постійно тримати зв'язок та обговорювати алгоритм виконання поставленого завдання. Після завершення учні мають зробити презентацію на 10-15 хвилин, розподіляючи відповіді за принципом рівності учасників, потім підготувати для решти учнів класу роздатковий матеріал у форматі А-5 3 основними датами, ключовими подіями та персоналіями. Такі презентації виконують всі групи для викладення теми у повному обсязі. На наступне заняття учні мають вивчити основний матеріал про події, викладені на підготовлених роздаткових картках та написати контрольну роботу [8].

Кожен учасник колаборативного навчання усвідомлює важливість подання своєї частини проблеми, бо це впливає на загальний результат всього класу. Протягом підготовки презентації учні мають тісний зв'язок з учителем, спілкуючись через Інтернет, на робочу е-адресу вчителя або після занять. Такі презентації виконуються 3 усіх предметів, окрім скажімо, з фізичного виховання та послуговують створенням психологічної, аналітичної бази для роботи з інформацією.

Подібні види колаборативної діяльності є підготовкою до здачі екзаменів у середній школі, який складається 3 двох частин: $60 \%$ усна презентація та $40 \%$ письмова. Учень має право вільного вибору теми на усний іспит, але обов' язково інтегрувати два навчальних предмети, наприклад: історія i мистецтво, фізика i математика тощо. Одним із головних критеріїв є креативне представлення матеріалу. Учні, зазвичай, обирають предмети, які вони планують вивчати далі для оволодіння майбутньою професією. Оцінюють презентацію два учителі 3 кожного предмета інтегрованого у презентації, класний керівник та замісник класного керівника. Письмова частина екзамену визначається вчителем, педагогічним колективом та відповідає змісту навчальної програми середньої школи.

Аналіз шведського досвіду показує, що системну підготовку вчителі можуть отримати лише, якщо проводити поступове, практичне навчання 3 розумінням 
можливостей сучасних технічних засобів i програмних засобів електронного призначення, психолого-педагогічних аспектів використання комп'ютерної техніки, враховуючи кваліфікацію, мотивацію, вік учасників навчального процесу [4].

Розроблено так звані «Карти ІКТ грамотності», які ілюструють перетин між технологічною складовою й педагогічно-рефлексивною. Стандарти, що запропоновані у цих документах, дають можливість педагогам зорієнтуватися, які конкретні знання і навички ІКТ-грамотності можуть бути інтегровані у змісті навчальних предметів, щоб відповідати вимогам 21 століття, створюючи умови для більш ефективного і якісного навчання та рівного доступу до освіти. Концептуальні засади, що лягли в основу розробки цих карт, базуються на IК компетентнісному підході і спрямовані на формування знань та умінь у шести напрямках. Для предметів суспільствознавчого циклу вони визначені, як: формування критичного мислення i навички вирішення проблем; контекстуальні навички; комунікативні навички; навички інформаційної і медіа грамотності; навички творчої та інноваційної діяльності; навички співпраці [4].

Справедливою видається думка переважної більшості шведських учених, які вважають післядипломну освіту вчителів 3 проблеми застосування IКТ найефективнішою, якщо вона здійснюється без відриву від виробництва в ході колаборативної проектної діяльності. Післядипломна освіта вчителів з використання IКТ зосереджується на таких напрямах:

- навчання вчителів Швеції на базі загальноосвітніх навчальних закладів у групах;

- забезпечення комп'ютером кожного учителя;

- виділення грантів на покращення мережного середовища загальноосвітніх навчальних закладів;

- створення е- адреси для вчителів і учнів;

- підтримка розвитку національної та європейської мережної взаємодії;

- заходи для соціальної опіки дітей з особливими потребами;

- нагороди за вагомі педагогічні досягнення.

Проектна робота з впровадження IKT у навчальну діяльність та створення відповідного начального комп'ютерно орієнтованого середовища мала підтримку уряду Швеції, освітня політика якого спрямована створення можливостей і нових 
сфер для самореалізації педагогів, студентів та всіх учасників навчального процесу. Відповідно до основних положень урядової політики щодо розвитку неперервного навчання першим кроком було створення умов для проведення заходів по перекваліфікації педагогів: початок першої частини проекту почався 3 визначення рівня ІКТ компетентності. Навчання для педагогів без відриву від виробництва надає змогу оцінити можливості розвитку та постійного взаємного збагачення й обміну досвідом саме серед колективу педагогів. Учителі самі були зобов'язані взяти відповідальність за своє навчання на робочому місці. Отже, учительські колективи ділили на групи (команди), усі учні були поділені на групи (команди). Кожна група вчителів разом із групами учнів планувала, розробляла та виконувала невеликі проектні завдання. Зазначимо, що всі учасники заохочувалися до використання IКТ та проблемного методу навчання. Проводилися комп’ютерні тренінги для вчителів. Такі заняття проходили без відриву від виробництва й охоплювали майже тритижневе стаціонарне навчання у вищому педагогічному закладі. Наступним кроком було навчання в групах разом з учнями. Протягом такої спільної роботи учителі й учні готували проектне завдання з обраної ними предметної тематики, міждисциплінарної проблеми тощо. Наведемо приклади тематики проектних досліджень: «Світ тварин»; «Хороше здоров’я»; «Корисний Інтернет»; «Стокгольм - столиця світу»; «Що розповідають листівки»; «Єдність природничих наук»; «Міжнародна співпраця у медицині». За часовими категоріями проектне навчання тривало протягом 4 місяців. Після завершення програмного проекту було внесено пропозицію щодо кількості i тривалості комп’ютерних тренінгів на робочих місцях [4].

У Швеції на сьогоднішній день вчителі мають у навантаженні 104 години навчання застосування IКТ у педагогічній діяльності протягом року на кожну школу [4]. Вони використовують на розвиток ІКТ-компетентностей частину проектного часу, частину викладацького часу та частину вільного часу. Для реалізації проектів були підготовлені вчителі-фасилітатори, які надавали консультації групі вчителів та учнів, а також консультанти 3 питань методичних. Такими консультантами могли бути вчителі 3 високим рівнем загально-педагогічної компетентності та міждисциплінарної методики. Велика кількість сформованих груп постійно зустрічалася на семінарах для обміну досвідом й обговорення. Семінари очолювали фасилітатори, а також викладачі-спеціалісти 3 IKT. Протягом постійно-діючих 
семінарів учасники презентували свої доповіді, де аналізували проведену роботу й обмірковували подальші перспективи. Окрім семінарів і тренінгів для вчителів і учнів були організовані тренінги для вчителів-фасилітаторів груп, для адміністрації шкіл, для муніципальної влади, та осіб - представників громадських організацій.

Розглянемо досвід роботи 3 впровадження IKT у навчальний процес загальноосвітньої школи Швеції у м. Остергьотленд на основі аналізу представлених звітів учителів та безпосереднього спостереження за навчальним процесом [8]. Діяльність проектної програми розпочалася з перекваліфікації вчителів. По-перше, було вирішено, що базові знання з ІКТ необхідні під час викладання будь-якого предмета. Спільне навчання ІКТ вчителів та учнів дало змогу оцінити можливості розвитку і постійного взаємозбагачення й обміну досвідом. Учителі свідомо взяли відповідальність за своє навчання на робочих місцях. Кожна команда, тобто вчителі разом з учнями, разом планували, розробляли і виконували невеликі проекти. У ході проектної діяльності всі учасники групи заохочуються до використання IКТ i реалізують проблемний підхід під час міжособистісної взаємодії. Кожна група отримувала постійну підтримку від керівництва школи, а також від консультантів(фасилітаторів, від муніципальної ради). Група вела журнал своєї діяльності (log book), де фіксувалися досягнення, прогрес у розв’язанні задач проекту за застосування IКТ.

У міжпроектний період учителі об’єднувалися для проведення семінарів, на яких вони обмінювалися досвідом, обговорювали пропозиції щодо покращення їх роботи й отримували подальші поради і заохочення для плідної співпраці. Наприкінці проекту кожен учитель писав свій звіт у формі наративу, який обговорювався 3 колегами, консультантами, професорами вищих педагогічних закладів [8].

Після успішного закінчення групового навчання на базі загальноосвітніх навчальних закладів вчителі-учасники проектів по всій території Швеції об'єдналися у 45 команд, створивши потужну мережу міжшкільної міжособистісної взаємодії. Про результативність проведення цих проектів красномовно свідчить про створення IКТ простору шведської освіти на індивідуальному, локальному і глобальному рівнях, що $€$ передумовою готовності й успішного входження шведської спільноти назустріч новим викликам інтенсивного розвитку інформаційного суспільства [5]. 
Поділяючи позиції шведських науковців (Gupea) щодо ролі Інтернеттехнологій у післядипломній педагогічній освіті, зазначимо, що ІКТ інтегрують свої інформаційні ресурси у педагогічний простір і надають доступ до інтегрованих інформаційних ресурсів широкому колу користувачів практично по всьому світу. Таку форму мережної педагогічної взаємодії часто називають всесвітнім класом, глобальною аудиторією. Водночас забезпечується як ретроактивний доступ до мережних ресурсів так і інтерактивна (on-line) взаємодія їх користувачів у процесі виконання ними спільних проектів, розв’язування єдиних навчальних завдань, взаємного інформування тощо.

Наступним важливим засобом отримання і поновлення знань упродовж життя $є$ віртуальна навчальна платформа, що передбачає залучення до навчальної діяльності в Інтернет-просторі учнів, учителів із сотнею тисяч шкіл усього світу під час виконання ними спільних міжнародних навчальних проектів із різних тем i дисциплін. Під кожний проект формується своя гнучка Інтернет орієнтована мережа учасників проекту (навчальних закладів, окремих осіб), що бажають взяти в ньому участь. Під час виконання навчальних завдань, реалізації спільних міжнародних навчальних проектів учні не тільки набувають, поглиблюють свої знання в певній предметній галузі, спілкуються між собою, обмінюються навчальними відомостями, поглиблюють свої знання з іноземних мов, знайомляться з культурою інших народів, формують i розвивають свої вміння і навички застосовувати IКТ, працювати в Інтернет-просторі, але й опановують основні підходи та сучасні інструменти проектного підходу в розв’язуванні різноманітних завдань (яскравим прикладом навчального застосування цих технологій $\epsilon$ проект «I*EARN» http://www.iearn.org.ua).

Цікавим з огляду на вище зазначену проблему є глобальна мережа вчителівноваторів (Innovative Teaches Network, створена компанією Microsoft за проектом "Партнерство в освіті”), що підтримують діяльність віртуальних спільнот освітян 3 усього світу, які ініціативно об’єднують свої зусилля в напрямі осучаснення змісту навчання i педагогічних технологій, обміну передовим педагогічним досвідом, апробації новітніх засобів навчання, обговорення нагальних і перспективних питань розвитку освіти. У зв'язку з цим у Швеції почали функціонувати ретельно організовані й розроблені програми, спрямовані на підвищення кваліфікації 
педагогічних кадрів. Наприклад, більшість, шведських університетів пропонують програми для продовження навчання тих, хто прагне удосконалюватись (Life Long Learning). Найчастіше - це дистанційні форми навчання. Наприклад, Upsala університет пропонує такі програми: 1) суспільна програма (Programme for the Public) — охоплює широкий вибір предметів, таких як історія, література, археологія, філософія, природничі науки, соціальні науки, регіональна історія, музика, психологія тощо; 2) індустріальна програма (Programme for Industry) - пропонує предмети, які відповідають вивченню індустрії; 3) юридична програма (Legal Studies Programme) для роботи в юридичній сфері; 4) інтернаціональні літні школи (International Summer Schools) — історія, соціологія, науки тощо [7].

Jonkoping університет пропонує курс (один рік навчання) для підвищення кваліфікації викладачів й отримання наукового знання за декількома спеціальностями (теорія і практика навчання, історія педагогіки, філософія педагогіки, психологія тощо). Щоб отримати ступінь, крім складання іспитів студенти повинні написати дослідницьку роботу [6].

Департаментом з питань освіти Швеції було розроблено Національну стратегію впровадження IКТ у зміст освіти середньої школи, що окреслила загальні підходи до просування IКТ технологій у шкільному навчанні. Національний навчальний план для середньої загальноосвітньої школи визначає знання і розуміння, уміння і навички 3 IКТ у чотирьох напрямах:

- знаходження інформації;

- вироблення ідей, критична оцінка та прийняття рішень;

- обмін і спільне користування інформацією;

- перегляд, редагування й оцінка роботи упродовж пошукової діяльності [8].

Перші три напрями містять у собі по три ключових поняття, тобто дев’ять концептуальних положень, що визначають рамки ІК компетентностей для середньої ланки загальноосвітньої школи. До першого напряму «Знаходження інформації» відносяться такі поняття як: робота 3 цифровими даними й інформаційними ресурсами; пошук і відбір інформації; організація інформації та іiі дослідження. Другий тематичний напрям «Вироблення ідей, критична оцінка та прийняття рішень» складається 3 положень: аналіз та автоматизація процесів; моделі та моделювання; контролювання та моніторинг. Третій - «Обмін та спільне користування 
інформацією» включає: обгрунтування придатності інформації для досягнення мети; удосконалення і представлення інформації; комунікативність. Четвертий тематичний напрям, а саме, «Аналіз, можливість внесення змін у роботу та іiі оцінка», $\epsilon$ найважливішим, який формує IКТ компетентності і має бути інтегрований в усіх інших напрямах та їх розгалуженнях. Очікується, що учні будуть навчатися в усіх напрямках, що складають ключові компетентності ІКТ. Такий підхід забезпечує основу для застосування і подальшого розвитку ІКТ для всієї навчальної програми.

Участь у науково-дослідній діяльності - це ще одна форма підвищення кваліфікації вчителів у міжкурсовий період. Для самовдосконалення професійної компетентності вчителі за власним бажанням можуть брати участь у роботі творчих груп, функціонування яких передбачено програмно-цільовими проектами (ПЦП).

Робота творчих груп організована за напрямами:

- розробка моделі формування інформаційно-комунікаційної компетентності вчителів-предметників загальноосвітніх навчальних закладів;

- розробка науково-методичного супроводу використання можливостей педагогічних програмних засобів навчального призначення як складової комп’ютерно орієнтованих методичних систем навчання в навчально-виховному процесі;

- розробка науково-методичного супроводу використання можливостей освітніх сайтів мережі Інтернет як складової комп’ютерно орієнтованих методичних систем навчання в навчально-виховному процесі [7].

У межах реалізації ПЦП проводяться також майстер-класи, під час яких учителі презентують власний досвід зі створення програмних засобів навчального призначення та їх використання у практичній діяльності, а також знайомлять 3 особливостями використання методу проектів на уроках, що передбачає застосування IKT.

На основі аналізу педагогічної літератури, спостережень за навчальним процесом охарактеризовано модель навчання педагогічної взаємодії в навчальному комп’ютерно орієнтованому середовищі, що суттєво впливає на розвиток рефлексивно-педагогічної складової. Модель поєднує такі компоненти: завдання, принципи, методи, форми, засоби і результати. Спільним завданням для вчителів і учнів $є$ сформувати ІКТ компетентність у процесі колаборативного навчання мережної взаємодії в умовах проектної діяльності. Диференційовані завдання 
стосуються досягнень у професійній і особистій сферах. До принципів навчання належать положення про науковість, системність, доступність, наочність, зв'язок практики з життям, рефлексія, самоактуалізація, відкритість, творчість, успіх, толерантність і добровільність, колаборативноість, матеріально-технічну підтримку. Серед активних методів навчання мережного спілкування виокремлено проблемний виклад інформації, евристичну бесіду, мозковий штурм, самоконтроль та взаємоконтроль, навчальне рецензування, тестування, наративи, портфоліо. Проектно-дослідницькі форми навчання міждисциплінарної і предметної тематики реалізуються шляхом утворення гетерогенних колаборативних груп зі складу вчителів і учнів, консультативних об'єднань, до яких входили науковці, освічені вчителі, технологічні працівники, менеджери. У числі засобів програмного забезпечення - PING PONG, PIM-Personal Information Manager, що дозволяє вести колективне планування та роботу над проектами, електронні ресурси, е-бібліотека (Jonkoping University Library). Отримані результати полягають у виявленні сформованої ІКТ компетентності у вчителів і учнів та наявності у них позитивної самооцінки, що виявляється в детермінації себе як активного користувача і творця навчального комп'ютерного орієнтованого середовища. Розроблена модель навчання педагогічної взаємодії в навчальному комп'ютерно орієнтованому середовищі створює умови для впровадження шведського досвіду у вітчизняну педагогічну практику.

Висновки. Отже, вивчення шведського досвіду освіти вчителів без відриву від виробництва показало, що зусилля шведських освітніх менеджерів спрямоване на практичне оволодіння учителями й учнями IКТ компетентностями в реаліях природного навчального процесу, який носить, водночас, дослідницький i прагматично-орієнтований характер. Проведене дослідження не претендує на повне висвітлення окресленої проблеми подальшого вивчення потребують питання підтримки ІКТ орієнтованої педагогічної діяльності вчителів освітніми менеджерами.

\section{Список використаних джерел}

1. Биков В. Ю. Моделі організаційних систем відкритої освіти: монографія / В. Ю. Биков. - К. : Атіка, 2008. - 684 с. 
2. Компетентнісний підхід у сучасній освіті: світовий досвід та українські перспективи / під заг. ред. О. В. Овчарук. - К. : «К.І.С.», 2004. — 112 с.

3. ICT in Teacher Education:Challenging prospects\Edited by Mohamed Chaib \& Ann-Katrin Svensson. — Jonkoping University Press / Encell. — 2005. — 250 p.

4. Chaib M. \& Svensson A. ICT AND TEACHER EDUCATION: A Lifelong Learning Perspective // ICT in Teacher Education. — 2005. — P. 5-20.

5. Sorensen B. ICT and schools in the information society: New Positions for Teachers // ICT in Teacher Education. - 2005. - P. 21-39.

6. Ahlbock T. \& Reneland L. Let's think about it : Considering the strengths of webbased collaboration // ICT in Teacher Education. - 2005. - P. 100-111.

7. Koenraad T. \& Parnell J. Pronett : Networking Education and Teacher Training // ICT in Teacher Education. - 2005. - P. 112-131.

8. Chaib C. Collaborative ict learning: Teachers' Experiences // ICT in Teacher Education. - 2005. - P. 178-197.

9. Web site. - World Economic Forum : 2012-2013 [Електронний ресурс]. Режим доступу : http://www.weforum.org.

\section{КОЛЛАБОРАТИВНЫЙ ПОДХОД К РАЗВИТИЮ ИКТ КОМПЕТЕНТНОСТИ УЧИТЕЛЯ И УЧЕНИКОВ ОБЩЕОБРАЗОВАТЕЛЬНЫХ УЧЕБНЫХ ЗАВЕДЕНИЙ ШВЕЦИИ}

Лещенко Мария Петровна, доктор педагогических наук, профессор, ведущий научный сотрудник Информационно-аналитического отдела педагогических инноваций Института информационных технологий и средств обучения НАПН Украины, г. Киев, e-mail: darlyngpetra@gmail.com.

Капустян Инга Ивановна, старший преподаватель кафедры английской и немецкой филологии Полтавского национального педагогического университета имени В. Г. Короленко, г. Полтава

\section{Аннотация}

В статье характеризуется шведский опыт коллаборативного подхода к последипломному обучению педагогов на базе общеобразовательных учебных заведений, который основывается на создании партнерских взаимодействий учителей с учениками в ходе коллективной проектной деятельности. Выяснено, что основными 
составляющими ИКТ компетентности шведского учителя являются мотивационная, технологическая и рефлексивно-педагогическая. Показано, что усилия шведских менеджеров в системе образования направлены на практическое овладение учителями и учениками ИКТ компетентностей в реальных условиях учебного процесса, который является одновременно исследовательским и прагматично-ориентированным.

Ключевые слова: шведский опыт, ИКТ в образовании, коллаборативный подход, мотивационная, технологическая, рефлексивно-педагогическая компетентность.

\section{COLLABORATIVE APPROACH TO THE DEVELOPMENT OF ICT COMPETENCE OF TEACHERS AND STUDENTS OF SECONDARY SCHOOLS IN SWEDEN}

Mariya P. Leshchenko, Doctor of pedagogical sciences, Professor, Chief researcher of Information and analitical department of pedagogical innovations, Institute of Information Technologies and Learning Tools of NAPS of Ukraine, Kyiv, e-mail: darlyngpetra@gmail.com.

Inga I. Kapustyan, Senior Lecturer, Department of English and German Philology of Poltava National Pedagogical University named after V.G. Korolenko, Poltava

\section{Resume}

In the article characterized the Swedish experience of collaborative approach to postgraduate teachers education at the secondary schools, which is to establish partnership agreements teachers interaction with students in the collective project activities. It was found that the main components of ICT competence Swedish teacher is motivational, technological, and educational reflexive. It is shown that the efforts of Swedish educational managers focused on the practical mastery of teachers and students of ICT competence in the realities of the natural learning process, which is at the same time, research and pragmatically-oriented nature.

Keywords: Swedish experience, ICT in education, collaborative approach, motivational, technological, reflexive and pedagogical competence. 